\title{
Scientiae thesaurus mirabilis: estudantes de origem brasileira na Universidade de Coimbra (1601-1850)
}

FERNANDO TAVEIRA DA FONSECA

Universidade de Coimbra

Já em outro lugar tivemos ocasião de referir o notável afluxo de estudantes de origem brasileira à universidade de Coimbra no período de 1700 a 1771. Os dados então apurados colocavam alguns dos agregados populacionais do Brasil - com grande destaque para a Baía e para o Rio de Janeiro - a par de outros continentais, nas posições cimeiras da hierarquia dos lugares que mais graduados haviam tido entre os seus naturais, durante aquele período'. Foi ainda possível dar conta do regime especial que, a partir de 1719, regulava a contagem do tempo da sua frequência, sendo-lhes comutados em um ano de mercê os dois períodos

Fonseca, Fernando Taveira -A universidade de Coimbra (1700-1771). Estudo social e económico. Coimbra: Por Ordem da Universidade, 1995, pp. 170-171, p. 196 e quadro A.II.5. a, b, c. 
Fernando Taveira du Fonseca

de quinze dias que eram concedidos aos reinícolas para fazerem as suas viagens de ida para a universidade e de regresso a suas casas ${ }^{2}$; de algumas peculiaridades relativamente à sua origem social ${ }^{3}$; ou da preferência acentuada que, de acordo com o padrão geral da frequência universitária coimbrã, manifestaram pelos estudos canonísticos, seguidos, a grande distância, pelos de Leis e de Medicina ${ }^{4}$.

Em outro estudo tivemos ocasião de nos debruçarmos sobre o papel desempenhado pelos estudantes e graduados ultramarinos, no continente ou em outros espaços, com especial destaque para os originários do Brasil.

O presente trabalho, alargando o período cronológico sob observação, procurará, sem pretensões de novidade, pormenorizar alguns aspectos no que diz respeito ao ritmo das matrículas e à origem geográfica dos estudantes brasileiros que cursaram na universidade de Coimbra ${ }^{6}$. A data

\section{'Ibidem, p. 74.}

${ }^{3}$ Ibidem, pp. 255 e 306-307.

4 Dos 808 estudantes que se graduaram entre aquelas duas datas, 74,5\% (602) eram canonistas, 19,8\% (160) haviam cursado Leis e 5,7\% (46) Medicina.

${ }^{5}$ Fonseca, Fernando Taveira - $O$ saber universitário e os universitários no Ultramar. In: História da Universidade em Portugal. Coimbra-Lisboa: Universidade de CoimbraFundação Calouste Gulbenkian, vol. I, tomo II, 1997, pp. 1017-1040.

' Utilizei como fonte de informação o elenco elaborado por Francisco Morais Estudantes da universidade de Coimbra nascidos no Brasil. Brasília, suplemento ao vol. IV, Coimbra, 1949. Com base nesta e em outras fontes elaborou Walter Cardoso uma comunicação, Estudantes da universidade de Coimbra nascidos no Brasil (1701-1822): procedências e graus obtidos. In Universidade(s). História, Memórias, Perspectivas. Actas do Congresso História da Universidade. Coimbra, 1991, pp. 166-179. Uma outra relação, também resultante da compilação de Francisco Morais, Estudantes brasileiros na universidade de Coimbra (1772-1872). Rio de Janeiro: Imprensa Nacional, 1943, não foi publicada pelo seu compilador e tem data dc edição anterior à do suplemento da Brasília. O cotejo das duas relações revela discrepâncias notáveis nos anos imediatos à Reforma de 1772. Trata-se, contudo de um diferente arranjo na colocação de alguns estudantes que haviam começado os seus cursos antes da Reforma e os prosseguiram a seguir a ela: o organizador da edição de 1943 colocou-os em 1772 ou depois; Francisco Morais, que assina as palavras introdutórias à relação publicada em 1949, assinalou a sua primeira matrícula, anterior à Reforma. É óbvio que nos conformámos com este último critério. 
escolhida como limite inicial - 1601 - marca o ponto em que começa a observar-se alguma regularidade nas vindas de além-Atlântico; no outro extremo - 1850 (o ano lectivo de 1849-1850) - pretendeu-se ultrapassar com alguma margem o momento da independência no sentido de verificar quais as consequências induzidas por esse acontecimento a curto e a médio prazo.

\section{O ritmo das matrículas}

O ponto de partida para a análise que nos propomos efectuar pode ser a observação do quadro 1 e do gráfico 1 , onde estão assinaladas as entradas anuais (primeira matricula) de estudantes originários do Brasil na universidade de Coimbra, durante dois séculos e meio. Antes de 1601, estas vindas não têm significado estatístico - são assinaladas treze entre 1577 e 1599, com vários anos em que nenhuma teve lugar. Não deixa, contudo de merecer reparo o facto de, muito pouco tempo depois de os registos universitários de matrículas se tornarem regulares ${ }^{7}$, neles figurarem estudantes brasileiros, o que deixa supor que já anteriormente alguns teriam iniciado os seus estudos em Coimbra

'O mais antigo livro de matrículas é de 1573-1574 (Vasconcelos, António de Escritos vários. Coimbra: Coimbra Editora , vol. II, 1941, p. 116.) Para o período que medeia entre 1537 e aquela data podem apenas colher-se elementos dispersos ou fazer estimativas a partir de outros dados (Fonseca, Fernando Taveira da - Os corpos académicos e os servidores. In: História da universidade em Portugal, vol. I, tomo II, pp. 533-535; Oliveira, António de - A vida económica e social de Coimbra. Coimbra: Instituto de Estudos Históricos Doutor António de Vasconcelos, 1971-1972, vol. II, apêndice, gráfico 94).

${ }^{8}$ Ao relatar os inícios da então província de Pernambuco, o autor da Corografia Brazilica refere que, em 1554, por morte de Duarte Coelho Pereira que obtivera a capitania do mesmo nome, em 1534, ficou o seu governo entregue à consorte, D. Brites de Albuquerque, "athé à chegada dc seu filho herdeiro, Duarte Coelho d'Albuquerque, que se achava no Reino estudando" (Corografia Brazilica ou Relação Historico- Geographica do Reino do Brazil composta I...] por hum presbítero secular do Grant Priorado do Crato. Rio de Janeiro: Na Impressão Regia, 1817, tomo II, pp. 153-154). 
Quadro 1

ESTUDANTES BRASILEIROS QUE SE MATRICULARAM EM COIMBRA (1601-1850)

VALORES QUINQUENAIS

\begin{tabular}{|c|c|c|c|c|c|}
\hline Quinquénios & Número & Média anual & Quinquénios & Número & Média anual \\
\hline 1601-1605 & 2 & 0,4 & 1731-1735 & 119 & 23,8 \\
\hline $1606-1610$ & 5 & 1,0 & 1736-1740 & 82 & 16,4 \\
\hline 1611-1615 & 9 & 1.8 & 1741-1745 & 120 & 24,0 \\
\hline $1616-1620$ & 11 & 2,2 & 1746-1750 & 99 & 19,8 \\
\hline $1621-1625$ & 3 & 0,6 & 1751-1755 & 119 & 23,8 \\
\hline $1626-1630$ & 13 & 2,6 & $1756-1760$ & 92 & 18,4 \\
\hline $1631-1635$ & 10 & 2,0 & 1761-1765 & 92 & 18,4 \\
\hline $1636-1640$ & 4 & 0,8 & 1766-1770 & 196 & 39,2 \\
\hline $1641-1645$ & 10 & 2,0 & 1772-1775 & 98 & 24,5 \\
\hline $1646-1650$ & 14 & 2,8 & 1776-1780 & 86 & 17,2 \\
\hline $1651-1655$ & 19 & 3,8 & 1781-1785 & 87 & 17,4 \\
\hline $1656-1660$ & 8 & 1,6 & 1786-1790 & 94 & 18,8 \\
\hline $1661-1665$ & 10 & 2,0 & 1791-1795 & 80 & 16,0 \\
\hline $1666-1670$ & 11 & 2,2 & 1796-1800 & 55 & 11,0 \\
\hline $1671-1675$ & 29 & 5,8 & 1801-1805 & 65 & 13,0 \\
\hline $1676-1680$ & 32 & 6,4 & 1806-1810 & 20 & 4,0 \\
\hline $1681-1685$ & 31 & 6,2 & 1811-1815 & 57 & 11,4 \\
\hline $1686-1690$ & 32 & 6,4 & 1816-1820 & 142 & 28,4 \\
\hline 1691-1695 & 65 & 13,0 & 1821-1825 & 121 & 24,2 \\
\hline $1696-1700$ & 50 & 10,0 & $1826-1830$ & 86 & 17,2 \\
\hline 1701-1705 & 18 & 3,6 & 1831-1835 & 11 & 2,2 \\
\hline 1706-1710 & 38 & 7,6 & 1836-1840 & 42 & 8,4 \\
\hline 1711-1715 & 13 & 2,6 & 1841-1845 & 46 & 9,2 \\
\hline 1716-1720 & 38 & 7,6 & $1846-1850$ & 36 & 7,2 \\
\hline 1721-1725 & 113 & 22,6 & & & \\
\hline 1726-1730 & 128 & 25,6 & TOTAL & 2761 & 11,1 \\
\hline
\end{tabular}

Os dados expressos e a curva desenhada pelas novas entradas de estudantes vindos do Brasil apresentam um perfil onde se destaca de imediato o grande salto positivo iniciado em 1720, que se prolonga, de forma sustentada, até à Reforma de 1772 (com um novo surto nos anos imediatamente anteriores a esta). Já antes, a partir dos meados da década de 1670 o crescimento se esboçara, para se esbater — à semelhança do 
que se passou com a curva geral da matrícula coimbrã - nos inícios do século XVIII".

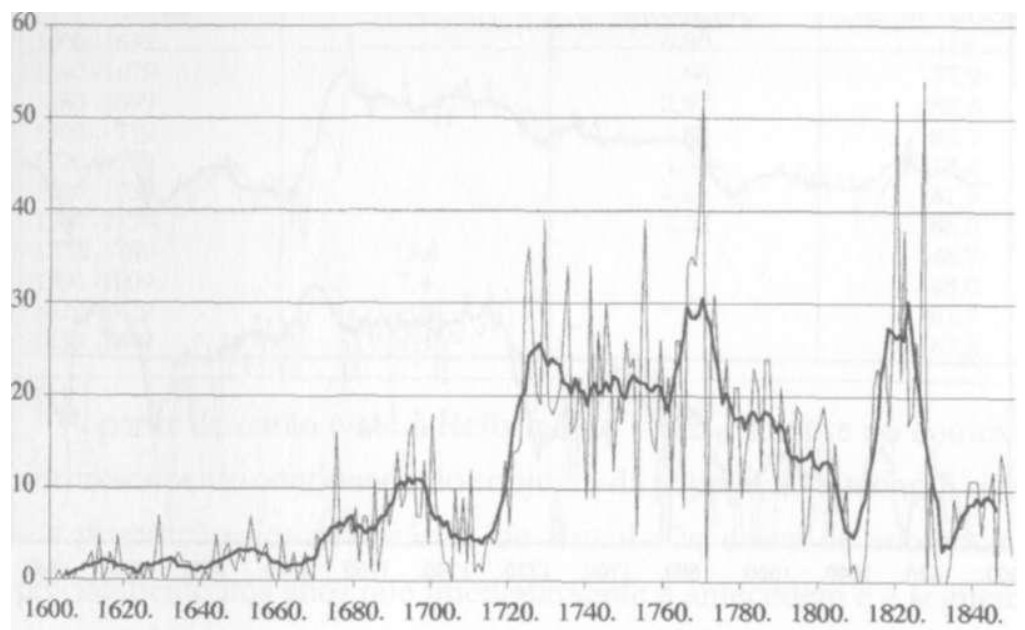

Gráfico 1 - Primeiras matrículas de brasileiros na Universidade de Coimbra

'Para a comparação com o ritmo geral das matrículas em Coimbra, vide Fonseca, Fernando Taveira - A universidade de Coimbra, pp. 30-37; Os corpos académicos, pp. 534-537. Tendo em consideração que a frequência das faculdades jurídicas representou

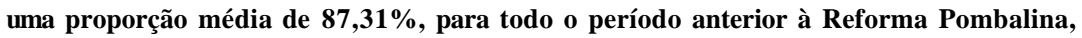
tomaram-se as matrículas em Instituta - corrigidas por um índice de 1,127 - como estimativa do total de novas entradas durante esse período. $O$ cômputo das primeiras entradas depois da Reforma de 1772, até 1820, foi feito por Manuel Alberto Carvalho Prata - Ciência e Sociedade. A faculdade de Filosofia no período pombalino e póspombalino (1772-1820). Dissertação de mestrado, policopiada, Guarda, 1989, pp. 57-74. Este autor tem o cuidado de apresentar separadamente os valores para os alunos ordinários de Matemática e Filosofia, os únicos que verdadeiramente se podem contabilizar como primeiras entradas nestas duas faculdades. Para o período posterior, utilizei as contagens de António de Vasconcelos (Escritos Vários, II, pp. 124-136). Neste último caso, os valores para Matemática e Filosofia, foram os referidos para o $4^{\circ}$ ano (no qual, em princípio, só existiriam alunos ordinários). 


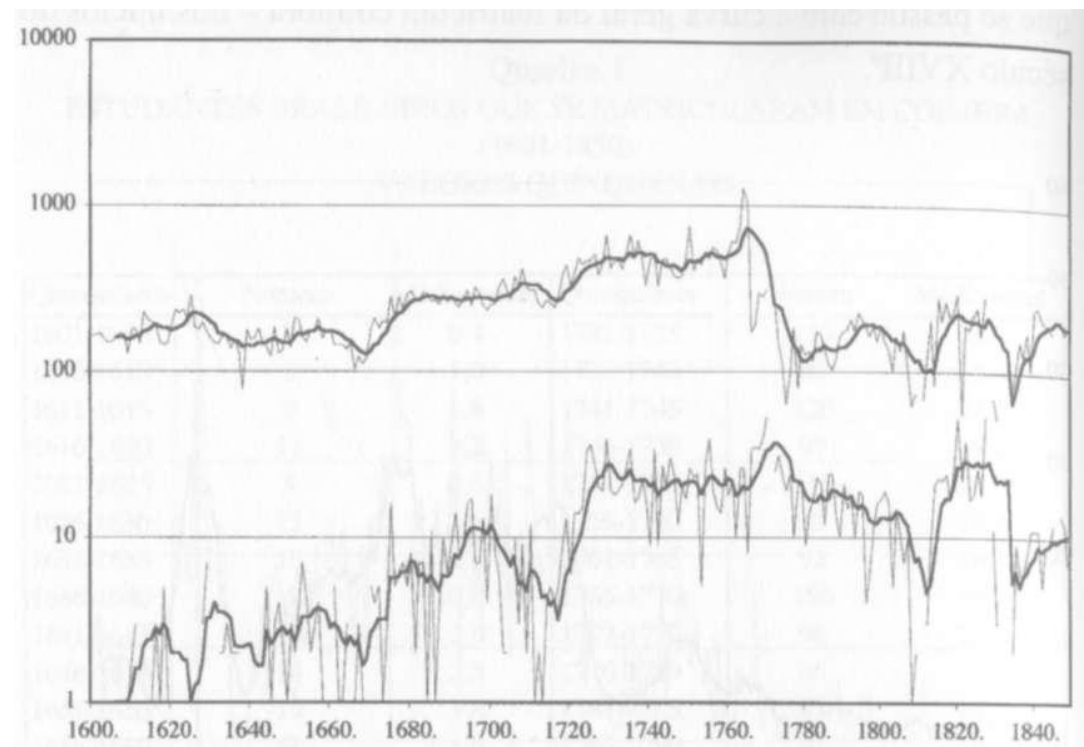

Gráfico 2 - Entradas de brasileiros comparadas com o total das primeiras matrículas

Esta semelhança com o ritmo global de novas entradas na universidade de Coimbra, visível no gráfico 2, no qual as duas curvas se encontram projectadas comparativamente - é caracterizada, contudo, por uma particularidade no que respeita à amplitude do movimento: o dos estudantes brasileiros é muito mais vigoroso. Por um lado, em termos absolutos, a média anual de ingressos mais que triplica relativamente à vintena de anos anterior, para se manter elevada nas décadas seguintes. Por outro, e mais significativo ainda - adoptando sempre como referência as inscrições em Instituta (corrigidas, de acordo com o critério enunciado na nota 9) como indicador global das primeiras entradas na universidade - podemos dar-nos conta que a percentagem que cabe aos brasileiros no cômputo geral dessas primeiras entradas se modifica substancialmente (quadro 2). 
Seientiae thesaurus mirabilis: estudantes de origem brasileira

\author{
Quadro 2
}

PRIMEIRAS MATRÍCULAS: PROPORÇÃO DE BRASILEIROS NO CONJUNTO DA POPULAÇÃO ESTUDANTIL DE COIMBRA

\begin{tabular}{|c|c|c|c|}
\hline Período & $\%$ & \% (conigida) & Coef. de variação $(\%)$ \\
\hline $1600-1639$ & & 0,80 & 118 \\
$1640-1679$ & & 1,66 & 77,9 \\
$1680-1699$ & & 2,97 & 58,6 \\
$1700-1719$ & & 1,88 & 87,7 \\
$1720-1739$ & & 4,56 & 31,4 \\
$1740-1759$ & & 4,61 & 41,9 \\
$1760-1770$ & 15,6 & 7,52 & 86,0 \\
$1772-1789$ & 7,4 & & 48,7 \\
$1790-1809$ & 11,6 & & 45,0 \\
$1810-1829$ & 4,3 & & 81,7 \\
$1830-1849$ & & & 67,8 \\
\hline
\end{tabular}

A partir de então e até à Reforma de 1772 - sempre no contexto de um crescimento continuado do conjunto da população estudantil coimbrã - a proporção dos originários do Brasil não cessa de aumentar. E é precisamente nos anos que imediatamente a antecedem e a seguem que são atingidos os valores máximos. Será preciso notar, contudo, que o período imediatamente antecedente é marcados por uma grande irregularidade no que diz respeito às novas matrículas: ao excesso de entradas dos anos de 1764-65 e 1765-66 ${ }^{10}$ sucedeu-se um quinquénio em que elas baixaram para níveis bastante inferiores. Deste modo, se naqueles dois anos a percentagem de brasileiros desce para 2,04\% e $0,77 \%$, respectivamente, já nos cinco seguintes é, em média, de 16,2\%: na totalidade destes sete anos antes da Reforma, a proporção dos brasileiros é de $12 \%$, correspondendo ao maior contingente que até então tinha demandado a universidade (com uma média anual de 39 novas entradas).

${ }^{10}$ Já tivemos ocasião de referir que na origem deste fenómeno esteve a legislação sobre recrutamento militar, então promulgada, a qual isentava das sortes "os Estudantes que nos Collegios e Universidades se applicão às artes e sciencias" (cfr. Fonseca, Fernando Taveira -A universidade de Coimbra, p. 122) 


\section{Fernando Taveira da Fonseca}

Mas é no quinquénio posterior a 1772 que melhor se nota o efeito deste acrescido contingente que acorre à universidade. Ao manter-se em níveis elevados - contrastando com a forte quebra que sofrem as matrículas dos continentais - vai traduzir-se em reforço da proporção de brasileiros: para todo o período de 1772 a 1788 , esta sobe para $16,5 \%$ em média, embora chegue pontualmente aos $30,2 \%$ (em 1775). A evolução das duas curvas do gráfico 2 faz-se, a partir dessa altura, em sentido divergente - diminuem em termos absolutos e relativamente às matrículas totais, as dos originários do Brasil - até que, a partir de 1813, uma nova aproximação se regista, num crescendo que só o encerramento da universidade, em 1828-29, vem interromper. O retomar dos trabalhos universitários foi fugaz: quando se reataram, depois de nova interrupção (de 1831-32 a 1833-34) e passada a guerra civil, foi débil o contingente dos que iniciaram os seus estudos universitários (pouco mais de sete dezenas, ao todo) e deles apenas 2 brasileiros: a proporção destes baixou significativamente para valores muito semelhantes aos do primeiro arranque (a partir 1720), mas bastante inferiores aos dessa época em termos absolutos, aproximando-se mais dos que a haviam precedido.

Em termos gerais, poderemos afirmar que o movimento longo de entradas de brasileiros na universidade de Coimbra que se inicia na terceira década do século XVIII, com um forte contingente, é marcado depois por uma lenta erosão, pouco sensível até meados dos anos sessenta, mais acentuada no período que começa uma década depois, mas cortada por dois ciclos de duração média que contrariam vigorosamente aquela tendência: o primeiro situa-se à volta da Reforma de 1772; o segundo toma balanço imediatamente a seguir à instalação da Corte portuguesa no Brasil como consequência das invasões francesas, e tem o seu máximo para lá de 1822 - em 1827 - só então iniciando a fase descendente.

Antes de tentarmos explorar o significado destes movimentos, teremos de dar-nos conta de outra característica que parece crucial para a sua 
compreensão. Refiro-me à origem geográfica destes estudantes que demandam a universidade de Coimbra: no contexto de um espaço que progressivamente se alarga, é imprescindível atentar neste aspecto.

2. A origem geográfica dos estudantes brasileiros

Ao abordarmos este outro momento de análise não poderemos deixar totalmente de lado a dimensão diacrónica que até aqui nos havia orientado. A razão fundamental já atrás ficou expressa: ao longo de grande parte do período que nos ocupa, o território brasileiro está em construção". Daí a necessidade de captar, também na frequência universitária, as implicações desse facto. O estabelecimento de marcos temporais teve por base a própria curva dos efectivos de primeiras matrículas: há indubitavelmente um antes e um depois de 1720, assim como é incontornável a Reforma de 1772 com o seu ciclo específico, como atrás assinalámos; conviria igualmente colocar uma cesura numa data próxima da ida da Corte para o Brasil, a partir da qual se inicia a fase ascendente de outro ciclo médio. Com base nestas referências, fezse uma divisão por períodos mais ou menos regulares. Os dados assim organizados foram reunidos no quadro A. 1. (em apêndice), e sintetizados no quadro 3.

É necessário, antes de mais, explicitar os critérios que conduziram á arrumação dos topónimos da forma que é apresentada. Uma das dificuldades encontradas foi a frequente utilização, na indicação da

${ }^{1}$ Magalhães, Joaquim Romero -A construção do espaço brasileiro. In: História da expansão portuguesa. Dir. de Francisco Bethencourt e Kirti Chauduri, Lisboa: Círculo de Leitores, vol. II, 1998, pp. 28 e ss. O autor reproduz um mapa de Fréderic Mauro no qual se assinalam os limites de Brasil em 1650, 1750 e 1800. É visível que, até àquela primeira data, o território ocupado se limitava a uma extensa faixa litoral apenas mais profunda na altura de Rio de Janeiro e de S. Paulo, sendo notável ainda a extensão das zonas insubmissas em 1800. 
Quadro 3

ORIGEM GEOGRÁFICA DOS ESTUDANTES BRASILEIROS QUE FREQUENTARAM A UNIVERSIDADE DE COIMBRA (1600-1850)

\begin{tabular}{|c|c|c|c|c|c|c|c|c|c|c|}
\hline \multirow[b]{2}{*}{ Designação } & \multicolumn{2}{|c|}{$1600-1720$} & \multicolumn{2}{|c|}{$1721-1771$} & \multicolumn{2}{|c|}{$1772-1810$} & \multicolumn{2}{|c|}{$1811-1850$} & \multicolumn{2}{|c|}{$1600-1850$} \\
\hline & $\mathbf{N}^{\circ}$ & $\%$ & $\mathbf{N}^{\circ}$ & $\%$ & $\mathbf{N}^{\circ}$ & $\%$ & $\mathbf{N}^{\circ}$ & $\%$ & $\mathbf{N}^{\circ}$ & $\%$ \\
\hline BRASIL & 16 & 3,38 & 3 & 0,26 & & & 1 & 0,19 & 20 & 0,72 \\
\hline BAÍA & 244 & 51,57 & 398 & 34,55 & 103 & 17.22 & 145 & 26,95 & 890 & 32,23 \\
\hline Outros lugares & & & 22 & 1,91 & 19 & 3,18 & 43 & 7.99 & 84 & 3,04 \\
\hline Total & 244 & 51,57 & 420 & 36,46 & 122 & 20,4 & 188 & 34,94 & 974 & 35,28 \\
\hline C SACRAMENTO & & & 15 & 1.3 & 5 & 0,84 & & & 20 & 0,72 \\
\hline GOIÁS & & & 6 & 0,52 & 10 & 1,67 & 4 & 0,74 & 20 & 0,72 \\
\hline MARANHÃO & & & 3 & 0,26 & 30 & 5,02 & 75 & 13,94 & 108 & 3,91 \\
\hline MINASGERAIS & & & 36 & 3,13 & 17 & 2,84 & 2 & $\mathbf{0 , 3 7}$ & 55 & 1,99 \\
\hline Mariana & & & 44 & 3.82 & 10 & 1,67 & 3 & 0,56 & 57 & 2,06 \\
\hline S. João d El Rei & 4 & 0.85 & 17 & 1.48 & 24 & 4,01 & 3 & 0,56 & 48 & 1,74 \\
\hline Sabará & & & 22 & 1,91 & 13 & 2,17 & 5 & 0,93 & 40 & 1.45 \\
\hline Vila Rica & & & 47 & 4.08 & 20 & 3,34 & 6 & 1,12 & 73 & 2.64 \\
\hline Outros lugares & & & 59 & 5,12 & 44 & 7,36 & 14 & 2,60 & 117 & 6,23 \\
\hline Total & 4 & 0,85 & 225 & 19.53 & 128 & 21,4 & 33 & 6,13 & 390 & 14,13 \\
\hline PARÁ & 2 & 0,42 & 9 & 0.78 & 17 & 2,84 & 16 & 2,97 & 44 & 1,59 \\
\hline PERNAMBUCO & 92 & 19,45 & 83 & 7,20 & 79 & 13,21 & 49 & 9,11 & 303 & 10,97 \\
\hline Outros lugares & 1 & 0,21 & 1 & 0,09 & 4 & 0.67 & 5 & 0.93 & 11 & 0,40 \\
\hline Total & 93 & 19,66 & 84 & 7,29 & 83 & 13,88 & 54 & 10,04 & 314 & 11,37 \\
\hline RIO DE JANEIRO & 100 & 20.93 & 314 & 27,27 & 144 & 24.08 & 103 & 19,14 & 661 & 23,94 \\
\hline Outros lugares & & & 7 & 0,61 & 14 & 2,34 & 23 & 4,28 & 44 & 1,59 \\
\hline Total & 99 & 21,14 & 314 & 27,26 & 149 & 24.92 & 126 & 23,42 & 688 & 24,95 \\
\hline S.PAULO & 4 & 0.85 & 25 & 2,17 & 19 & 3,18 & 9 & 1,67 & 57 & 2.06 \\
\hline Santos & 5 & 1,06 & 24 & 2,08 & 7 & 1.17 & 1 & 0,18 & 37 & 1.34 \\
\hline Outros lugares & & & 1 & 0,09 & 1 & 0,17 & 6 & 1,12 & 8 & 0,29 \\
\hline Total & 9 & 1,9 & 50 & 4,34 & 27 & 4,52 & 16 & 2,97 & 102 & 3,69 \\
\hline OUTROS & 3 & 0,63 & 11 & 0,95 & 16 & 2,67 & 23 & 4,28 & 53 & 1,92 \\
\hline Não identificados & 2 & 0,42 & 5 & 0,43 & 2 & $\mathbf{0 , 3 3}$ & 2 & 0.37 & 11 & 0,4 \\
\hline TOTAL & 473 & 100.00 & 1152 & 100,00 & 598 & 100,00 & 538 & 100.00 & 2761 & 100,00 \\
\hline
\end{tabular}

naturalidade dos estudantes, de nomes designando áreas vastas (capitanias, províncias, comarcas...) que são, muitas vezes, coincidentes com a designação do seu agregado populacional mais importante, o que torna difícil determinar qual das duas referências escolher. Em contrapartida, essa indicação mais genérica revelou-se de grande utilidade 
Scientiae thesaurus mirabilis: estudantes de origem brasileira

quando acompanhava a dos outros topónimos, permitindo assim uma mais fácil identificação e localização destes. Deste modo, no quadro geral, apresentado em apêndice, mantiveram-se todas as designações encontradas (depois de reduzidas a uma só as variantes que designavam um mesmo agregado ${ }^{12}$ ) subordinando-as à área mais ampla em que se enquadravam, umas vezes por referência explícita da fonte de informação, outras como resultado da sua identificação e localização. No quadrosíntese (quadro 3) reduziu-se a multiplicidade das designações, mantendo explícitas as que designavam espaços mais vastos ou os seus agregados principais (em termos de frequência universitária) e agrupando as restantes sob a rubrica de "outros lugares"13.

Na representação cartográfica (mapas 1 a 4) seguiu-se um critério semelhante, agregando numa mesma superfície circular sombreada, centrada no seu agregado mais importante, a totalidade dos contributos de uma área, e assinalando com circunferências os de outras localidades que se revelassem quantitativamente significativos ${ }^{14}$.

A conjugação dos dados numéricos com a representação cartográfica permite algumas observações interessantes. Antes de mais, a grande

${ }^{12}$ Em alguns casos (por exemplo Rio das Mortes e S. João d'el Rei ou Mariana e Ribeirão do Carmo) mantiveram-se os diferentes nomes por um se ter sucedido a outro na designação do mesmo agregado.

${ }^{13} 0$ principal instrumento utilizado para a identificação e localização dos topónimos foi a Corografia Brazilica ou Relação Historico-Geografica do Reino do Brazil composta e dedicada a Sua magestade fidelissima por hum presbítero secular do Gram Priorado do Crato. 2 tomos, Rio de Janeiro: Na Impressão Regia, 1817. Para uma localização contemporânea foram utilizados vários atlas, nomeadamente o Atlas 2000. A nova cartografia do mundo. Lisboa: Círculo de Leitores, s.d.

${ }^{14}$ Quer as áreas sombreadas, quer as circunferências que aparecem no interior ou na proximidade daquelas são proporcionais ao número de estudantes originários da região em que são colocadas. Será importante referir que as circunferências são apenas explicitações ou desmembramentos da área geral sombreada, não podendo, por isso acumular-se àquelas. A proporcionalidade adoptada é de carácter exponencial (com base na fórmula da superfície do círculo). 


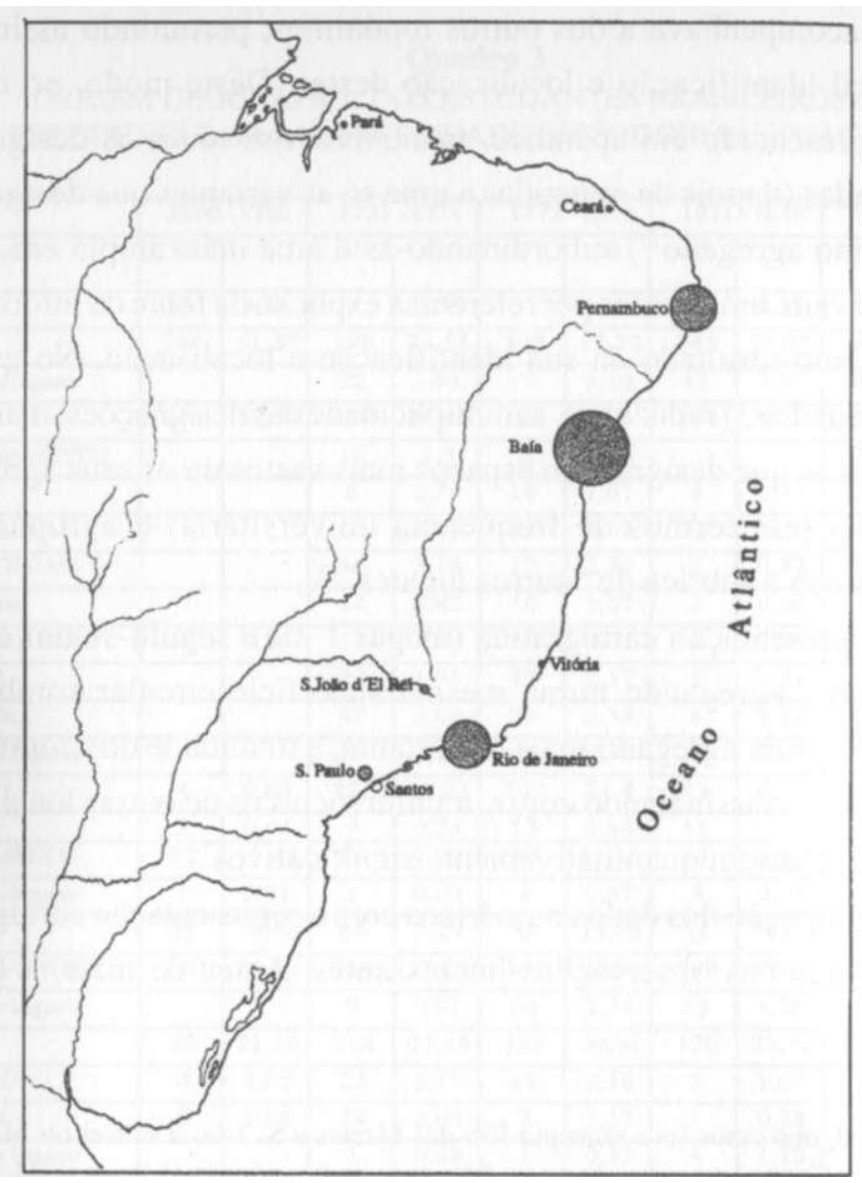

Mapa 1 - Origem geográfica dos estudantes brasileiros (1600-1720)

concentração - em termos de designação mas presumivelmente também em termos reais - em alguns agregados populacionais dos diversos espaços considerados ${ }^{15}$. Este fenómeno tem a sua tradução nas baixas

${ }^{15}$ Haja em vista que é a designação de alguns deles que depois se estende, por um processo de ampliação, a espaços maiores. Podemos exemplificar com o caso de Pernambuco: "Este nome Pernambuco, derivado ou corrupção de Paranânbuca, com que os Cahetés designavam o porto, onde hoje [1817] surgem as embarcações menores, 


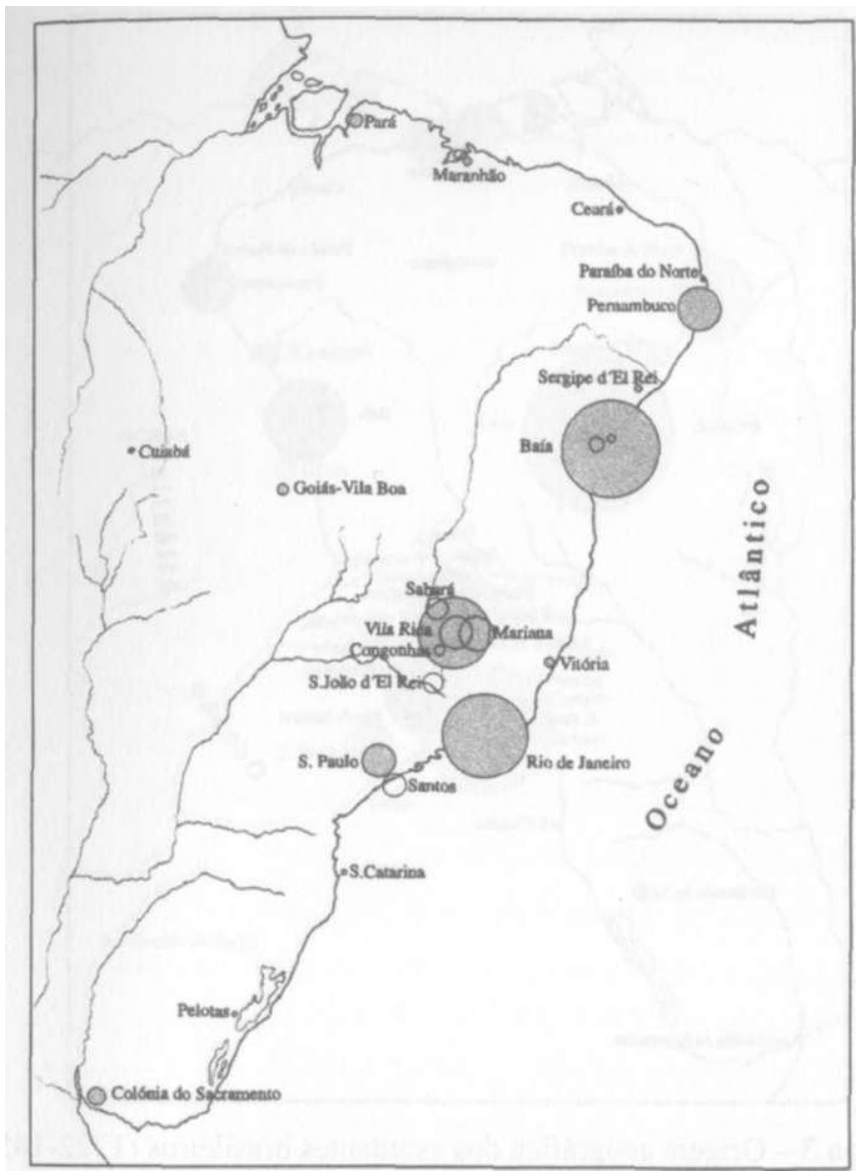

Mapa 2 - Origem geográfica dos estudantes brasileiros (1721-1771)

percentagens de estudantes originários de "outros lugares", no quadro 3. No primeiro grande intervalo cronológico (1600-1720), são pouquíssimas

comprehende vulgarmente duas Povoações distinctas, a Cidade d'Ollinda, e a Praça ou Villa do Recife, com o intervallo de huma legua, e comunicadas por uma restinga de area estreita, e baixa de N. a S. e também por um braço de mar" (Corografia Brazilica, tomo II, pp. 170-171). No momento da recolha das informações, verificámos que eram raras as referências ao Recife e a Olinda (22 em 314), o que se deve evidentemente ao facto de ser mais comum a designação de Pernambuco englobando aquelas duas localidades e depois a capitania. 


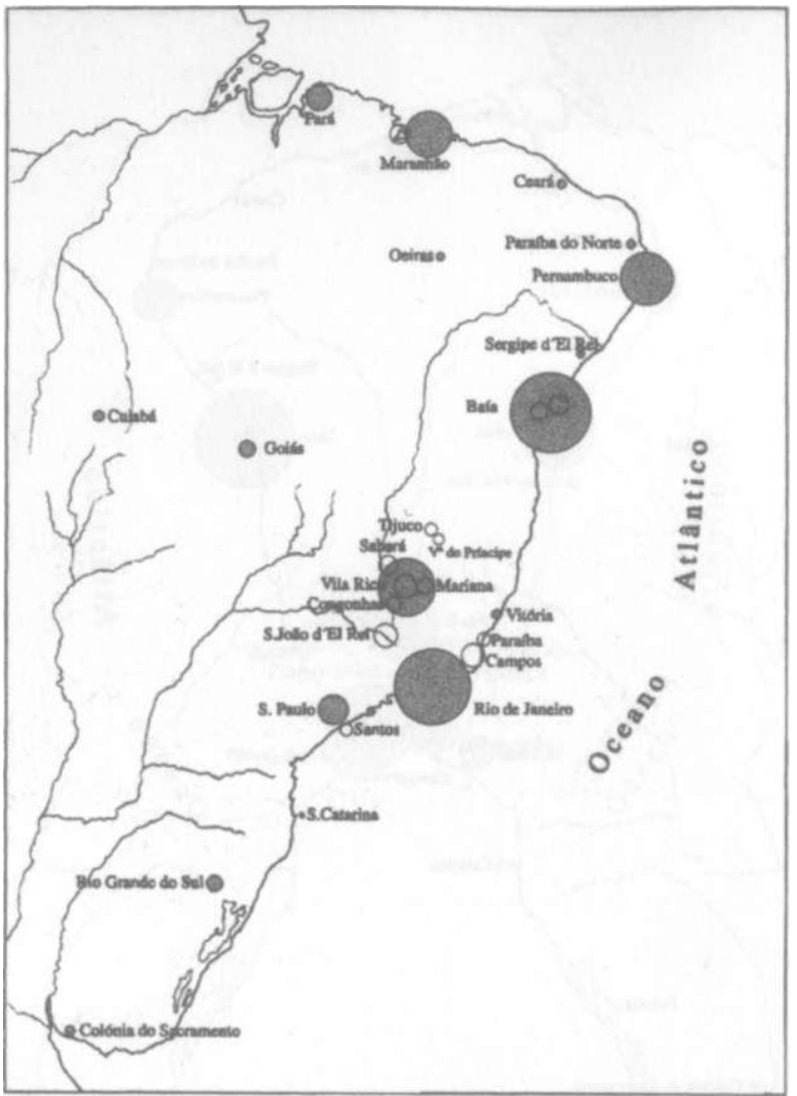

Mapa 3 - Origem geográfica dos estudantes brasileiros (1722-1850)

as designações toponímicas (todas cartografadas no mapa $1^{16}$ ), desde logo constituindo uma estrutura que se irá manter como dominante, sobretudo nos seus três grandes centros de captação de estudantes

${ }^{16}$ Embora a província de Minas Gerais tenha sido criada apenas em 1720, nos quadros toponímicos ficou sempre nela incluída a vila de S. João d' El Rei, que passa a ter esta designação a partir de 1712, mas que pertencia, até àquela primeira data, a $S$. Paulo (Corografia Brazilica, tomo I, pp. 356 e 377). 


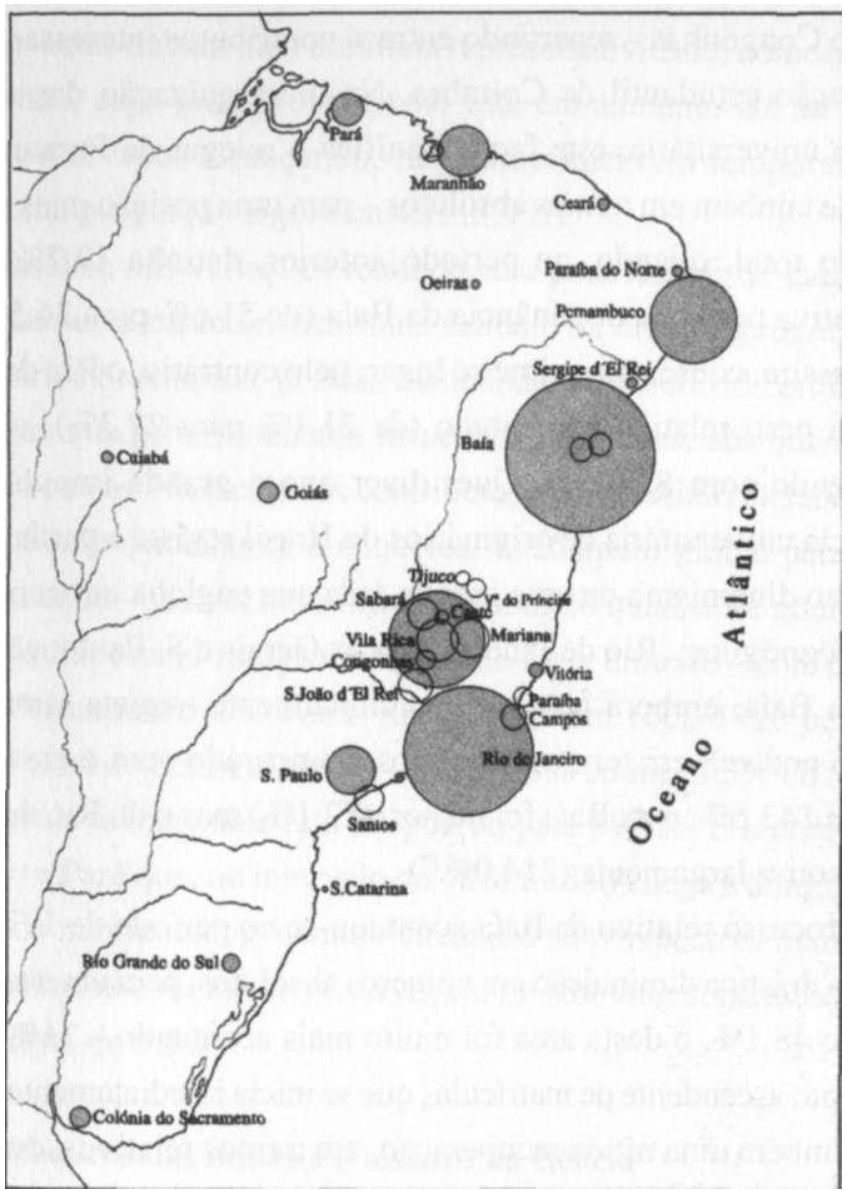

Mapa 4 - Origem geográfica dos estudantes brasileiros (1600-1850)

universitarios - Baía, Rio de Janeiro e Pernambuco - com o conjunto S.Paulo-Santos com alguma representatividade, mas a bastante distância daqueles. A grande novidade do período seguinte - 1721-1771 - é a entrada em força da região mineira. Não se trata, realmente, apenas de uma nova designação, derivada da criação da provincia de Minas Gerais, em 1720, mas da inclusão de um novo espaço, neste caso com vários agregados - Mariana, Vila Rica de Ouro Preto, Sabará, S. João d'El Rei 
e mesmo Congonhas - repartindo entre si contributos interessantes para a população estudantil de Coimbra. Na hierarquização das áreas de captação universitária, este facto significa o relegar de Pernambuco que perde também em termos absolutos - para uma posição mais modesta (7,3\% do total, quando, no período anterior, detinha 19,7\%) e uma significativa perda na dominância da Baía (de $51,6 \%$ para $36,5 \%$ ) que, mesmo assim, conserva o primeiro lugar; pelo contrário, o Rio de Janeiro vê o seu peso relativo aumentado (de $21,1 \%$ para $27,3 \%$ ), o mesmo acontecendo com S. Paulo. Quer dizer que o grande impulso que a frequência universitária de originários do Brasil regista a partir de 1720 se deve ao dinamismo de uma grande área que engloba um conjunto de espaços contíguos: Rio de Janeiro, Minas Gerais e S. Paulo; ao mesmo tempo, a Baía, embora perca proporcionalmente, regista também um aumento notável, em termos absolutos: comparado com o crescimento global de $143,6 \%$, o da Baía foi menor $(72,1 \%)$ mas o do Rio de Janeiro ultrapassou-o largamente $\left(214,0 \%{ }^{17}\right)$.

O retrocesso relativo da Baía acentuou-se no período de 1772-1810, com uma drástica diminuição em números absolutos: para um decréscimo global de 48,1\%, o desta área foi muito mais acentuado - 71\%. Mas o movimento ascendente de matrículas que se inicia imediatamente a seguir marca também uma nítida recuperação, em termos relativos, desta área: em contrapartida, a de Minas Gerais sofre uma diminuição acentuada (de $74 \%$, muito maior que a dos efectivos globais, que foi de apenas $10 \%)$, perdendo assim muitos pontos da sua cota proporcional. Mas o dado que mais importa assinalar é a emergência, a partir de 1772, de

${ }^{17}$ É evidente que estas percentagens têm de ser ponderadas a partir da proporção que cabe a cada um destes espaços. Por isso, carece de significado apresentar a percentagem de crescimento de $S$. Paulo $(455,6 \%)$ uma vez que se refere a um aumento de 9 para 50 estudantes, em números absolutos, assim como referir igual indicador para Minas Gerais, área que praticamente aparece de novo. 
zonas que antes tinham uma diminuta representatividade, nomeadamente o Maranhão, cujo peso proporcional está em aumento até ao final do período observado, alcançando, no último intervalo temporal (1811-1850), uma proporção significativa $(13,9 \%)$.

Esta análise das variações relativas não pode deixar de lado aquela que parece ser a característica mais saliente da origem geográfica dos universitários brasileiros, já atrás assinalada: uma notável continuidade dos centros que primitivamente fornecem estudantes, aos quais se vão agregando outros. Na escala dos contributos, só o de Minas Gerais alcança uma amplitude semelhante à daqueles. O cômputo global para toda a duração secular - visível nas últimas colunas do quadro 3 e no mapa 4 vem confirmar esta afirmação: a Baía - no lugar cimeiro - com o Rio de Janeiro, Pernambuco e S. Paulo-Santos (que em 1600-1720 perfaziam $94,3 \%$ do total de matriculados ${ }^{18}$ ) tomam à sua conta $75,3 \%$ do total. As Minas Gerais fazem subir esta proporção para $89,4 \%$. E o conjunto de Maranhão e Pará que, no intervalo de 1811 a 1850 chega a atingir 16,9\% de todos os matriculados, quando encarado na perspectiva mais ampla dos dois séculos e meio sob observação, mostra uma contribuição bem mais modesta de $5,5 \%$.

3. Os tesouros das minas e o tesouro da ciência

Da análise que temos vindo a efectuar até este momento destaca-se o grande aumento que, comojá referimos, se regista no número de novas entradas na universidade de estudantes brasileiros, a partir de 1720. A verificação de que um impulso semelhante percorre a frequência

${ }^{18}$ Durante este período é ainda de assinalar a percentagem $(3,38 \%)$ dos que declaram como sua naturalidade apenas o Brasil. Não seria demasiada ousadia pensar que se trataria de naturais de algum daqueles lugares, o que nos permitiria dizer que a quase totalidade de brasileiros é deles originária. 


\section{Fernando Taveira da Fonseca}

universitária, considerada globalmente, leva a concluir que para um e outro terão contribuído idênticas condições de possibilidade e idênticas motivações ${ }^{19}$.

Mesmo tendo sempre em mente a especificidade da sociedade brasileira é certo que, em muitos aspectos, se transplantaram para a colónia formas de organização e valores dominantes na sociedade continental. Referindo-se à organização administrativa do Brasil, afirma Joaquim Romero Magalhães que "a construção do império atlântico, pela proximidade de Lisboa e pela relativa facilidade de transportes, não exigiu a montagem no Brasil de um dispositivo de governo delegado, como o que existia no Oriente. [...] As vilas e cidades que entretanto iam sendo criadas eram administradas segundo o modelo normal que vigorava no reino. [...] A justiça era exercida por juízes ordinários que se encontravam à frente das câmaras" ${ }^{20}$. Por sua vez, Caio Boschi acentua o papel do sistema paroquial como base do trabalho missionário e da administração eclesiástica, tendo sido em função da existência de paróquias "(desde os anos 30 do século XVI) e, sobretudo, da importância do seu trabalho que, dentre outras razões, se decidiu, em 1551 pela criação da diocese de Salvador, na Bahia"ı1. E não podemos esquecer que os horizontes dos que demandavam Coimbra, vindos de além-Atlântico, não se confinavam ao exercício das qualificações universitárias nos espaços da sua naturalidade: estava-lhes aberto todo o império, assim como o acesso aos cargos da administração central do reino ${ }^{22}$.

Tivemos ocasião de referir em outro lugar as condições do crescimento da frequência universitária, a partir da terceira década do século XVIII (cfr. Fonseca, Fernando Taveira - A universidade de Coimbra, pp. 112-117).

${ }^{20}$ Magalhães, Joaquim Romero - A construção do espaço brasileiro. In: História da Expansão Portuguesa, vol. 2, p. 28.

${ }^{21}$ Boschi, Caio - A religiosidade laica. In: História da Expansão Portuguesa, vol. 2, p.419.

${ }^{22}$ Cfr. Fonseca, Fernando Taveira da - $O$ saber universitário $e$ os universitários no Ultramar. In: História da universidade em Portugal. Vol. I, tomo II, pp. 1030-1032. 
Observámos, contudo, que o impulso ascendente referido é, no que toca aos originários do Brasil, de muito maior amplitude que o da matricula geral. Devido a dois factores principais: o aparecimento de um novo espaço - Minas Gerais - e o incremento que anteriores zonas de captação universitária (nomeadamente o Rio de Janeiro) experimentaram.

Não será nunca demasiado salientar o papel catalizador que a descoberta das jazidas de ouro e diamantes tiveram na fixação de uma nova geografia do Brasil e na dinamização da economia brasileira. A colorida descrição de André João Antonil, impressa em 1711, dá-nos conta da poderosa atracção que elas exerceram:

"A sêde insaciável do ouro estimulou a tantos a deixarem suas terras, e a meterem-se por caminhos tão asperos, como são os das minas, que difficultosamente se poderá dar conta do numero das pessoas, que actualmente lá estão. Comtudo os que assistirão nellas nestes ultimos annos por largo tempo, e as corrêrão todas, dizem, que mais de trinta mil almas se occupão, humas em catar, outras em mandar catar nos ribeiros do ouro; e outras em negociai", vendendo, e comprando o que se ha mister não só para a vida, mas para o regalo, mais que nos portos do mar"23

A animação do comércio era motivada pela carência de tudo o que era necessário à subsistência - "sendo a terra que dá ouro esterilissima de tudo o que se ha mister para a vida humana e não menos esteril a maior parte dos caminhos das minas" - e também pela abundância e qualidade dos meios de pagamento:

${ }^{23}$ Antonil, André João - Cultura e opulencia do Brazil por suas drogas e minas. Com um estudo bio-bibliographico por Affonso de E. Taunay. S. Paulo: Companhia de melhoramentos de S. Paulo, 1922, p. 213. 
"...tanto que se vio a abundancia do ouro, que se tirava, e a largueza, com que se pagava tudo o que la hia; logo se fizerão estalagens, e logo começarão os mercadortes a mandar às minas o melhor que chega nos navios do reino, e de outras partes, assim de mantimentos, como de regalo, e de pomposo para se vestirem, além de mil bugiarias de França, que lá tambem foram dar. E a este respeito, de todas as partes do Brazil se começou a inviar tudo o que dá a terra, com lucro não somente grande mas excessivo. E não havendo nas minas outra moeda mais que ouro em pó; o menos que se podia, e dava por qualquer cousa, erão oitavas. Daqui se seguiu mandarem-se às Minas Geraes as boiadas de Paranaguá, e às do Rio das Velhas, as boiadas dos campos da Bahia, e tudo o mais que os moradores imaginavão poderia apetecer-se, de qualquer genero de cousas naturaes, e industriaes, adventicias, e proprias" ${ }^{24}$

Importa atentar em dois aspectos: por um lado, a fixação de gente, dando origem a arraiais de exploração que depois se ampliam em agregados populacionais que atingem notoriedade e vão sendo dotados de armadura administrativa ${ }^{25}$; por outro, a circulação de víveres nomeadamente o gado vivo - e mercadorias, através de rotas e caminhos, alguns já conhecidos e percorridos, outros explorados agora. Assume

${ }^{24}$ Ibidem, p. 217.

${ }^{25}$ O arraial de Ouro Preto foi fundado em 1697, por António Dias de Oliveira. Em 1711 é elevado à categoria de vila, com o nome de Vila Rica; Mariana fora também arraial do Carmo, até que na mesma data, D. João V a tomara Vila Leal do Carmo, elevando-a à categoria de cidade episcopal em 1745 e dando-lhe o nome da sua consorte; só em 1712 foram também criadas as vilas de S. João d'El Rei (antes Rio das Mortes) e Vila Real do Sabará e, cm 1714, a Vila do Príncipe. Outros exemplos poderiam ser aduzidos, mas importa ainda referir que, nas proximidades destes centros se formaram numerosos arraiais muitos dos quais depois deram origem a paróquias (Piranga, Catas Altas, Arraial de António Pereira, Santa Bárbara, Cocais, S. Romão, Barra do Rio das Velhas, S. António do Tijuco...) de alguns dos quais vieram também estudantes para Coimbra. Assinale-se outra forma de implantação como era a construção de capelas, necessárias para a assistência religiosa às populações, de que há numerosíssimos exemplos na região mineira (cfr. Corografia Brazilica, pp. 363-402). 
particular importância, neste contexto, o "caminho novo", aberto, em 1704-1705 por Garcia Rodrigues Pais (mas ficando a passagem em boas condições só por volta de 1725), ligando a região mineira ao Rio de Janeiro. Encurtava-se de trinta para doze dias o tempo necessário para vencer aquela distância ${ }^{26}$. Consequentemente, o Rio de Janeiro "o mais próximo ancoradouro de ligação de Minas à Europa e também à África fornecedora de escravos, cresce e ganha uma importância no todo do território que até então não tivera. Por aí também se canalizava obrigatoriamente o ouro dos quintos devido à Fazenda real. [...] Ao Rio de Janeiro passa agora a caber a função de servir como "boca das Minas" sobretudo pela sua posição marítima" ${ }^{27}$.

Reorganiza-se, deste modo, o espaço brasileiro, não sem desequilíbrios, uma vez que a afluência de gente e de escravos à zona das Minas desguarnece sobretudo a área de produção açucareira do Nordeste, e que a carestia de vida - e também a da mão-de-obra que era preciso adquirir $^{28}$ - vai a par com e radica na própria extracção do minério. Não será de estranhar que esses mesmos desequilíbrios se tenham reflectido no número de candidatos à frequência universitária, levando, como já verificámos à perda da importância relativa da Baía e, sobretudo, de Pernambuco.

${ }^{26}$ Viana, Hélio - História da viação brasileira. Rio de Janeiro: Biblioteca do Exército, 1949, pp. 114-115.

${ }^{27}$ Magalhães, Joaquim Romero - As novas fronteiras do Brasil. In: História da Expansão Portuguesa, vol. 3, pp. 23-24.

${ }^{28}$ É, a este propósito, muito elucidativa a relação dos preços (referidos a 1703) que Antonil insere na sua Cultura e opulencia do Brazil, pp. 218-220, no fim da qual acrescenta o seu comentário: "E estes preços tão altos, e tão correntes nas minas, forão causa de subirem tanto os preços de todas as cousas, como se experimenta nos portos das cidades e villas do Brazil, e ficarem desfornecidos muitos engenhos de assucar das peças necessarias; e de padecerem os moradores grande carestia de mantimentos, por se levarem quasi todos, aonde vendidos hão de dar maior lucro" (p. 220). 


\section{Fernando Taveira da Fonseca}

Não se trata, contudo, de subversão. O caso do Rio de Janeiro é típico e exemplar. Aí convergem duas ordens de razões que vão explicar o extraordinário aumento verificado: o novo dinamismo económico e a existência de uma infra-estrutura de ensino que terá sido a principal responsável pela afluência de brasileiros à universidade no período anterior (1600-1720). Sem que se possa dar um peso exclusivo a este factor - basta lembrar a importância da Baía como capital administrativa - ele terá constituído a ossatura básica geradora de uma apetência intelectual que, uma vez enraizada, permanece e se amplia.

No conjunto da rede de ensino pré-universitário, os três colégios jesuíticos da Baía, do Rio de Janeiro e de Pernambuco, estavam, juntamente com alguns outros do continente (Lisboa, Porto, Braga e Santarém - a partir de 1716 - e, naturalmente, Évora) e o dos oratorianos de Lisboa (só a partir de 1708), em posição privilegiada, pois o primeiro ano dos estudos filosóficos que neles fosse concluído era contabilizado como se tivesse sido cursado nas faculdades jurídicas de Coimbra. Pelo Catalogo dos P.P. e Irmãos da Provincia do Brasil em Janeiro de 600 ${ }^{29}$, temos notícia de que, nesse ano, o colégio da Baía tinha um lente de Teologia, um outro de Casos de Consciência, um mestre do curso de Artes, assim como outros três de Gramática (um da primeira classe e dois da segunda, um destes também mestre de ler e escrever).

Um século depois, dos 157 jesuítas que o Colégio alimenta (118 vivendo no próprio edifício, 33 nas aldeias e residências a ele anexas), dois ensinam Teologia Especulativa, um Teologia Moral, um Filosofia, dois Humanidades e outros dois Gramática e um primeiras letras ${ }^{30}$. O

Leite, Serafim - História da Companhia de Jesus no Brasil. Lisboa-Rio de Janeiro: Livraria Portugália-Civilização Brasileira, tomo I, 1938, Apêndice L, pp. 578 e ss.

Catalogus rerum temporalium, 1701. Status habitualis provinciae brasilicae. apud Leite, Serafim - História da Companhia de Jesus no Brasil, tomo V, 1945, Apêndice E, pp. 588 e ss. 
edifício do colégio é descrito como "satis extensum" e localizado na parte melhor da cidade, com uma biblioteca ampla e abundante, contendo cerca de três mil volumes de todo o género de escritores que se pudesse desejar, seis grandes aulas rodeando o pátio - havia pouco circundado de pórticos para proteger os estudantes do sol e da chuva -, uma sala de maiores dimensões destinada às disputas públicas, aos actos literários e também aos exercícios dos escolares da ordem.

Em 1757, o corpo docente do Colégio aparece reforçado com um especialista em Sagrada Escritura ("explanator Sacrae Scripturae") provavelmente apenas para os da casa, porque a relação dos mestres das classes superiores inclui um prefeito máximo, três professores de Teologia (de Prima, de Véspera - segundo a nomenclatura universitária - e de Teologia Moral), um professor de Matemática (da "faculdade de Matemática", como refere o Catálogo que vimos seguindo), um prefeito das classes menores, encarregado da biblioteca, e um mestre de Filosofia com o seu substituto; nas classes inferiores, um professor de Retórica, três de Gramática (da primeira, segunda e terceira classes) e um professor da escola elementar de meninos que era também director da sua confraria $^{31}$. A descrição que da cidade do Salvador nos dá a Corografia Brazilica de 1817 refere que, nessa altura, há na cidade oito cadeiras régias: de Filosofia, de Retórica, de Matemática, de Grego e quatro de Gramática Latina, para além de "uma Biblioteca Pública na Salla do Collegio ex-Jezuitico, que servia do mesmo mister no tempo dos fundadores ${ }^{32}$.

O exemplo da Baía - e não aduzimos outros de cariz semelhante para não alongar inutilmente esta exposição - é significativo daquela

${ }^{3}$ Catalogus Brevis Provinciae Brasiliensis an. 1757, apud Leite, Serafim - História da Companhia de Jesus no Brasil, tomo VII, 1949, Apêndice G, pp. 435 e ss.

${ }^{32}$ Corografia Brazilica, tomo II, p.120. 
continuidade que a implantação de uma estrutura de ensino é susceptível de gerar. Os jesuítas criaram e desenvolveram um sistema que, à semelhança do que aconteceu no reino, gerou as condições da sua pronta substituição pela abertura que sempre teve ao exterior. Ao traçar, no tomo VI da sua História da Companhia de Jesus no Brasil, o percurso do Colégio do Rio de Janeiro, Serafim Leite chama a atenção para a evolução física do edifício e para a ampliação das disciplinas leccionadas, que o colocavam, nessa altura, a par do da Baía. Mas observa igualmente que oito dos onze professores que formavam o corpo docente desse mesmo Colégio eram naturais do Brasil: "três paulistas, dois pernambucanos, um alagoano, um do Rio, um da Baía". E acrescenta: "prepondera Santos, donde são naturais todos aquêles paulistas, contemporâneos de Alexandre e Bartolomeu de Gusmão, que, por sua vez foram alunos dos Padres, e o segundo mais que aluno, porque foi noviço" ${ }^{33}$.

O Catalogus brevis de 1757 fornece-nos sinteticamente o panorama da implantação dos jesuítas na província do Brasil nas vésperas da sua expulsão. Eram, ao todo, 476 sócios, em diversas casas de diferente dimensão e finalidade: os colégios e, na sua dependência, residências, aldeias, missões. Para a finalidade que aqui directamente nos ocupa, interessa, sobretudo dar conta dos colégios e instituições afins: o Colégio da Baía, cuja composição já observámos; aí ainda, uma casa de provação e dois seminários (o de Belém, fundado pelo P. Alexandre de Gusmão, e o novo); o Colégio do Rio de Janeiro com professores de Teologia (3), de Filosofia (1 com o seu substituto), dois professores de Gramática, um de Retórica, um da escola elementar e dois prefeitos dos estudos; o Colégio de Paranaguá com um mestre de Gramática; o do Espírito Santo (Vitória), com um mestre de Gramática e um padre encarregado da 
resolução de casos de consciência; o Colégio de S. Paulo com um mestre de Teologia Moral, outro de Gramática e um da escola elementar; o Colégio de S. Miguel, em Santos, com prefeito dos estudos ao qual estava também confiado o encargo de resolver os casos de consciência, um professor de Gramática e outro da escola elementar; o Colégio de Olinda com um professor de Filosofia que era também prefeito dos estudos, um substituto deste, um mestre de Gramática e um professor da escola elementar de meninos; o Colégio do Recife, com um professor de Teologia Moral que era igualmente prefeito dos estudos, mestres da $1^{\mathrm{a}} \mathrm{e}$ $2^{a}$ classes de Gramática e um da escola elementar; o Colégio e seminário de Paraíba com um director do seminário que era também prefeito dos estudos, um professor de Gramática e outro da escola elementar; o Real Hospício do Ceará, em Aquirás, também com um professor de Gramática que tinha a seu cargo a biblioteca.

Na vice-província do Maranhão, o Colégio de Nossa Senhora da Luz, que atingira o estatuto de colégio máximo, em 1709, depois que, aos estudos de Latim, Humanidades e Retórica se haviam acrescentado os de Filosofia e de Teologia Especulativa e Moral $^{34}$; dele dependiam outras casas nas quais se ministrava o ensino do Latim (na própria cidade de $\mathrm{S}$. Luís, na missão de Guanaré e na Parnaíba); uma estrutura semelhante se criou no Pará - o Colégio de Santo Alexandre, que apenas não teve permanentemente estudos de Teologia dogmática; a ele anexo a casa da Vigia, com ensino de primeiras letras e Latim e o seminário de Nossa Senhora das Missões, onde funcionou também o curso de Filosofia. As bibliotecas destas casas - a do Colégio de S. Luís, com cinco mil volumes, com mais de dois mil a do Colégio de Santo Alexandre, e a da casa da Vigia com mais de mil - somariam, com outras de menores dimensões, um total de doze mil, em $1760^{35}$.

\footnotetext{
${ }^{34}$ Ibidem, tomo IV, pp. 262-265.

${ }^{35}$ Ibidem, tomo IV, pp. 287-290.
} 
É visível a diferente graduação destes colégios, alguns apenas com o ensino elementar e da Gramática, outros com estudos de nível superior, embora, nalguns casos, com dificuldades de implantação e intermitências. Mas importa salientar a intenção sistemática de fazer acompanhar a missionação da difusão do saber - ou de considerar esta como forma privilegiada de acção pastoral.

Quando elabora a sua Corografia Brazilica, já diversas vezes aqui citada, o P. Manuel Aires do Casal tem o cuidado de assinalar esta que fora a presença dos jesuítas, dando conta do destino de muitos dos edifícios que eles tinham construído e utilizado no seu labor, a maior parte deles transformados em residências de governadores, hospitais ou palácios episcopais. O aspecto mais interessante para nós, contudo, é a atenção que ele presta às estruturas de ensino - nomeadamente as cadeiras régias - que vai encontrando nos diversos agregados populacionais que descreve ${ }^{36}$. Assinala dezanove localidades onde há aulas régias de Gramática Latina e outras dezassete nas quais a estas se juntam as primeiras letras. Cuiabá (Mato Grosso) e Vila Rica (Minas) têm, além disso, professor régio de Filosofia. Os centros mais dotados são, contudo, aqueles onde, desde mais longa data, se enraizara o estudo. S. Paulo tem professores desde as primeiras letras à Gramática, Retórica e Filosofia; mas a cidade está dotada também com uma cadeira régia de Teologia Dogmática e uma outra de Teologia Moral financiada pela mitra ${ }^{37}$. Na

${ }^{36}$ Uma atenção que parece constante, a julgar pelo comentário que ele faz a propósito da então província do Piauí: "O Subsídio Litterario, imposto no gado desta provincia, he assaz importante: mas em oitocentos e oito ainda não havia nella uma cadeira de Primeiras Letras, nem de Latim: sem duvida por não terem sido pedidas; pois que d'humas, e outras se vêm em algumas aldêas d'outras províncias" (Corografia Brazilica, tomo II, p. 250).

${ }^{37}$ Um dos aspectos curiosos desta obra é o comentário prospectivo que, por vezes, complementa a descrição da realidade coeva. Acerca de S. Paulo, afirma: "A salubridade, e temperamento do clima, a abundancia, e barateza de viveres fazem julgar que se lhe dará preferencia para a premeditada fundação da Universidade, que lhe dará crescimento, 
Baía, para além das cadeiras já atrás mencionadas e da biblioteca pública, o antigo edifício do colégio jesuítico alberga o hospital da tropa, onde há Aula de Cirurgia. Impressivo é também o caso de Pernambuco, onde o Recife conta com três professores régios de Latim, um de Filosofia e outro de Eloquência e Poética, mas onde Olinda, cidade episcopal desde 1676 e "uma bella habitação para estudiosos, convalescentes e melancolicos, que aborrecem os tumultos" tem um seminário no colégio ex-jesuítico com aulas e professores de Latim, Grego, Francês, Geografia, Retórica, Historia Universal, Filosofia, Desenho, História Eclesiástica, Teologia Dogmatica e Moral. No Norte, tanto S. Luís do Maranhão como Belém do Pará têm professores de Latim, Retórica, e Filosofia. Por fim, o Rio de Janeiro, sede da Corte desde 1807, com dois seminários e o antigo colégio dos jesuítas transformado em Hospital Real Militar dotado de Aulas de Cirurgia ${ }^{38}$, uma Academia da Marinha, várias aulas de primeiras letras, três de Latim, uma de Grego, assim como de Retórica, de Filosofia, de Comércio, de Desenho, e algumas de línguas vivas. A biblioteca real, com mais de sessenta mil volumes, estava franqueada ao público.

Não se implantara ainda, apesar da "inversão brasileira" que a ida da Corte motivara, o estudo do Direito e da Medicina, permanecendo Coimbra - e outras universidades europeias, tais como Montpellier e as

lustre, commercio, e celebridade. Os corpos tem aqui mais vigor para a applicação; e os insectos damnificam menos as Bibliotecas" (tomo I, p. 236). A cidade tinha então "nuns quatro mil e vinte vizinhos com vinte e tres mil setecentos e sessenta habitantes" (p. 235)

${ }^{38} \mathrm{O}$ curso de Cirurgia durava cinco anos com um currículo que incluía a Anatomia, a Química, a Farmacêutica, a Fisiologia, A Higiene, a Etiologia, a Patologia, a Terapêutica, a Obstetrícia, Instituições Cirúrgicas, e a prática da Medicina. Aos que, concluído o $5^{\circ}$ ano, voltassem a repetir o quarto e quinto anos, era-lhes concedida a graduação de tomados em Cirurgia (Corografia Brazilica, tomo II, p. 29). 


\section{Fernando Taveira da Fonseca}

de Inglaterra e da Alemanha ${ }^{30}$ - como etapa necessária daqueles que queriam prosseguir estudos superiores nestes domínios ou nos das Ciências Exactas e Naturais. O ciclo ascendente que se iniciou logo após a ida da Corte para o Rio de Janeiro marcou também uma reformulação do equilíbrio relativo dos lugares de origem dos estudantes brasileiros, uma vez que a Baía - agora com um conjunto de lugares menores que de perto a circundavam - retomava a posição hegemónica, em contraste com uma diminuição muito acentuada de Minas Gerais.

No cômputo global, os efeitos dos tesouros das Minas e a semente de cultura lançada e longamente sazonada - o inestimável tesouro da ciência - não podem ser dissociados, e aparecem-nos como elementos fundamentais para a compreensão da procura acrescida de qualificações académicas dos estudantes originários do Brasil.

3 Vargues, Isabel Nobre - Apresentação. In: De Tiradentes às Escadas de Minerva. Exposição biográfica e bibliográfica. Coimbra: Faculdade de Direito, 1999, p. XVI, Silva, Maria Beatriz Nizza da - A cultura luso-brasileira. Da reforma da Universidade à independência do Brasil. Lisboa: Editorial Estampa, 1999, pp. 24-27. 
Quadro A.1 - Origem geográfica dos estudantes brasileiros

\begin{tabular}{|c|c|c|c|c|c|c|c|c|c|c|c|c|c|c|c|c|}
\hline Designação & $1600-$ & $1641-$ & $1681-$ & 1701- & & 1721- & $1741-$ & 1761- & & $1772-$ & 1791- & & $1811-\mathrm{j}$ & 1831- & & \\
\hline Brasil & \begin{tabular}{|l|l|}
1640 \\
14
\end{tabular} & 1680 & & & 10 atal & \begin{tabular}{|l|l|}
$1 / 40$ \\
2
\end{tabular} & & $1 / 11$ & $\frac{10 \text { all }}{3}$ & 1790 & & Total & $\begin{array}{c}1830 \\
1\end{array}$ & & $\begin{array}{r}0 \text { Total } \\
1\end{array}$ & \begin{tabular}{|r|} 
TOTAL \\
\end{tabular} \\
\hline Bala & 11 & 84 & 92 & 57 & 244 & 190 & 114 & 94 & 398 & 62 & 41 & 103 & 129 & 16 & 145 & 890 \\
\hline Báa-Cachoeira & & & & & & 2 & 5 & 3 & 10 & 6 & & 6 & 8 & & $\mathrm{t}$ & 24 \\
\hline Baía-Cairu & & & & & & & & & & & 1 & $\mathbf{1}$ & 1 & & 1 & 2 \\
\hline Baía-Cotinguiba & & & & & & & & & & & 1 & 1 & & & 1 & 2 \\
\hline Baáa-Iguape & & & & & & & & & & & & & 1 & & 1 & 1 \\
\hline Báa-Itapagipe & & & & & & & & & & & & & 1 & & $\mathbf{1}$ & 1 \\
\hline Báa-Itapicuru & & & & & & & & & & & & & & 1 & 1 & 1 \\
\hline Báa-Jacobina & & & & & & & 1 & & $\mathbf{1}$ & 1 & & 1 & 2 & & 1 & 3 \\
\hline Báa-Jaguaripe & & & & & & & & & & & & & 1 & & 1 & 1 \\
\hline Baía-Maragogipe & & & & & & & & 2 & $\mathbf{1}$ & & 2 & 1 & 1 & & 1 & 3 \\
\hline Baí-Monforte & & & & & & 1 & 2 & & 3 & & & & & & & 3 \\
\hline Báa-Muritiba & & & & & & & 1 & & $\mathbf{1}$ & 1 & & 1 & & & & 2 \\
\hline Baía-Nazaré & & & & & & & & & & 1 & & 1 & & & & 1 \\
\hline Báa-Rio das Contas & & & & & & & & 1 & 1 & 2 & & 2 & 2 & & 2 & 5 \\
\hline Baía-Rio das Contas (Minas do) & & & & & & & 1 & & 1 & & & & & & & 1 \\
\hline Báa-Rio Fundo & & & & & & & & & & 2 & & 2 & 1 & & 1 & 3 \\
\hline Baía-S. Antonio de Vila Nova & & & & & & & & & & & 1 & 1 & & & & 1 \\
\hline Baía-S. Domingos de Sabará & & & & & & & & & & & & & 1 & & 1 & 1 \\
\hline Báa-S. Félix & & & & & & & & & & & & & 2 & & 2 & 2 \\
\hline Baía-S.Francisco & & & & & & $\mathbf{1}$ & & & $\mathbf{1}$ & 1 & & $\mathbf{1}$ & & & & 2 \\
\hline Baía-Santa Ana do Camisão & & & & & & & & & & & & & $\mathbf{1}$ & & 1 & 1 \\
\hline Baía-Santo Amaro & & & & & & $\mathbf{1}$ & & & 1 & & 1 & 1 & 16 & 1 & 17 & 19 \\
\hline Báa-Santo Amaro da Purificação & & & & & & 1 & 1 & & 2 & & & & 1 & & 1 & 3 \\
\hline Báa-Valença & & & & & & & & & & & & & $\mathbf{1}$ & & 1 & 1 \\
\hline Báa-Vila Nova de Boipeba & & & & & & & & & & & & & $\mathbf{1}$ & & 1 & 1 \\
\hline Total & & & & & 244 & & & & 420 & & & 122 & & & 188 & 974 \\
\hline Capitania do Espírito Santo & & & & & & & 4 & & 4 & $\mathbf{1}$ & $\mathbf{1}$ & 2 & & & & 6 \\
\hline Capitania do Espirito Santo-Vitória & & & & 1 & 1 & & & & & 2 & & 2 & & & & 3 \\
\hline Total & & & & & 1 & & & & 4 & & & 4 & & & & 9 \\
\hline
\end{tabular}




\begin{tabular}{|c|c|c|c|c|c|c|c|c|c|c|c|c|c|c|c|c|}
\hline Designação & \begin{tabular}{|l|}
$1600-$ \\
1640
\end{tabular} & $\begin{array}{c}1641- \\
1680\end{array}$ & \begin{tabular}{c|}
$1681-$ \\
1700
\end{tabular} & $\begin{array}{c}1701- \\
1720 \\
\end{array}$ & Total & \begin{tabular}{|c|}
$1721-$ \\
1740
\end{tabular} & \begin{tabular}{|c|}
$1741-$ \\
1760
\end{tabular} & $\begin{array}{c}1761- \\
1771\end{array}$ & Total & $\begin{array}{c}1772- \\
1790\end{array}$ & $\begin{array}{r}1791- \\
1810\end{array}$ & Total & \begin{tabular}{|c|}
$1811-$ \\
1830
\end{tabular} & \begin{tabular}{|l|l|}
$1831-$ \\
1850
\end{tabular} & Total & TOTAL \\
\hline Ceará & & & & 1 & 1 & & & 1 & 1 & & & & 1 & & 1 & 3 \\
\hline Ceará- Aracati & & & & & & & & & & & 1 & 1 & 1 & & 1 & 2 \\
\hline Ceará-Januária & & & & & & & & & & & & & & 1 & 1 & 1 \\
\hline Total & & & & & 1 & & & & 1 & & & 1 & & & 3 & 6 \\
\hline Colónia do Sacramento & & & & & & & 10 & 5 & 15 & 4 & 1 & 5 & & & & 20 \\
\hline Goiás & & & & & & & & & & & & & 3 & & 3 & 3 \\
\hline Goiás-Meia Ponte de (Goiases) & & & & & & & 1 & & 1 & 5 & & 5 & & & & $\frac{5}{6}$ \\
\hline Goiases & & & & & & & & 1 & 1 & & & & & & & 1 \\
\hline Goiases-Minas de Goiases & & & & & & & & 1 & 1 & & 1 & 1 & & & & 2 \\
\hline Goiases-Minas de Goiases-Santa Ana & & & & & & & 1 & & 1 & & & & & & & 1 \\
\hline Goiases-Vila Boa & & & & & & & 2 & & 2 & 2 & 2 & 4 & 1 & & 1 & 7 \\
\hline Total & & & & & & & & & 6 & & & 10 & & & 4 & 20 \\
\hline Maranhão & & & & & & & & & & 3 & 15 & 18 & 32 & 16 & 48 & 66 \\
\hline Maranhão-Alcântara & & & & & & & & & & & 6 & 6 & 7 & 6 & 13 & 19 \\
\hline Maranhão-Campo Maior & & & & & & & & & & & 1 & 1 & 1 & & 1 & 2 \\
\hline Maranhão-Caxias & & & & & & & & & & & & & 1 & 2 & 3 & 3 \\
\hline Maranhão-Peagim & & & & & & & & 1 & 1 & & & & & & & 1 \\
\hline Maranhão-SLúís & & & & & & 2 & & & 2 & 3 & 2 & 5 & 3 & 6 & 9 & 16 \\
\hline Maranhão-Viana & & & & & & & & & & & & & 1 & & 1 & 1 \\
\hline Total & & & & & & & & & 3 & & & 30 & & & 75 & 108 \\
\hline Mato Grosso-Cuiabá & & & & & & & & & & 1 & 2 & 3 & 1 & & 1 & 4 \\
\hline Mato Grosso-Cuiabá- Minas do Bom Jesus & & & & & & & & & & 1 & & 1 & & & & 1 \\
\hline Mato Grosso-Santo António & & & & & & & 1 & & 1 & & & & & & & 1 \\
\hline Total & & & & & & & & & 1 & & & 4 & & & 1 & 6 \\
\hline Minas Gerais & & & & & & 12 & 18 & 6 & 36 & 14 & 3 & 17 & 1 & 1 & 2 & 55 \\
\hline Minas Gerais-Borda do Campo & & & & & & & & 1 & 1 & 1 & & 1 & & & & 2 \\
\hline Minas Gerais-Caeté-Vila Nova da Rainha & & & & & & & 2 & $\frac{1}{2}$ & 4 & $\frac{1}{2}$ & & $\frac{1}{2}$ & 1 & & 2 & 8 \\
\hline Minas Gerais-Carijós & & & & & & & & 1 & 1 & & & & & & & 1 \\
\hline Minas Gerais-Catas Altas & & & & & & & 1 & & 1 & 2 & & 2 & & & & 3 \\
\hline Minas Gerais-Congonhas do Campo & & & & & & & & 2 & 2 & 4 & 1 & 5 & 5 & & 5 & 12 \\
\hline Minas Gerais-Congonhas do Sabará & & & & & & & 3 & & 3 & 1 & & 1 & & & & 4 \\
\hline Minas Gerais-Jacuí & & & & & & & & & & & & & 1 & & 1 & 1 \\
\hline Minas Gerais-Lancôes & & & & & & & 1 & & 1 & & & & & & & 1 \\
\hline
\end{tabular}




\begin{tabular}{|c|c|c|c|c|c|c|c|c|c|c|c|c|c|c|c|c|}
\hline Designação & $\begin{array}{l}1600- \\
1640\end{array}$ & $\begin{array}{l}1641 \\
1680\end{array}$ & $\begin{array}{l}1681- \\
1700\end{array}$ & $\begin{array}{c}1701 \\
1720\end{array}$ & Total & $\begin{array}{l}1721- \\
1740 \\
\end{array}$ & \begin{tabular}{|c}
$1741-$ \\
1760
\end{tabular} & $\begin{array}{c}1761- \\
1771 \\
\end{array}$ & Total & $\begin{array}{l}1772-j \\
1790 \\
\end{array}$ & $\begin{array}{r}1791- \\
1810\end{array}$ & Total & \begin{tabular}{|l|}
$1811-$ \\
18301
\end{tabular} & $\begin{array}{r}1831- \\
1850 \\
\end{array}$ & Total & TOTAL \\
\hline Minas Gerais-Mariana & & & & & & & 32 & & 44 & & 3 & 10 & & & 3 & 57 \\
\hline Minas Gerais-Ribeirão do Carmo & & & & & & 4 & 4 & & 8 & & & & & & & \\
\hline Minas Gerais-Mariana-Arraial de António Pereira & & & & & & & & & & 1 & & 1 & & & & 1 \\
\hline Minas Gerais-Mariana-Campanha de Rio Verde & & & & & & & & & & 2 & & 2 & & & & 2 \\
\hline Minas Gerais-Mariana-Casa Branca & & & & & & & & 1 & 1 & & & & & & & 1 \\
\hline Minas Gerais-Mariana-Inficionados & & & & & & & 1 & 2 & 3 & & & & & & & 3 \\
\hline Minas Gerais-Maríana-Monsus & & & & & & & I & & 1 & & & & & & & 1 \\
\hline Minas Gerais-Mariana-S. Bartolomeu & & & & & & & 1 & & 1 & & & & & & & 1 \\
\hline Minas Gerais-Mariana-Salcclas & & & & & & & & 1 & 1 & & & & & & & 1 \\
\hline Minas Gerais-Mariana-Vila do Príncipe & & & & & & & & & & 1 & & 1 & & & & 1 \\
\hline Minas Gerais-Minas Novas dos Fanados & & & & & & & & 1 & 1 & & & & & & & 1 \\
\hline Minas Gerais-Na Sr. da Natividade & & & & & & & & & & 3 & & 3 & & & & 3 \\
\hline Minas Gerais-Ouro Branco & & & & & & & 1 & & 1 & 1 & & 1 & & & & 2 \\
\hline Minas Gerais-Paracatu & & & & & & & & 2 & 2 & 1 & & 1 & 2 & & 2 & 5 \\
\hline Minas Gerais-Pitangui & & & & & & & 2 & & 2 & 2 & & 2 & & & & 4 \\
\hline Minas Gerais-Pouso Alto & & & & & & & & & & & & & 1 & & 1 & 1 \\
\hline Minas Gerais-Rio das Mortes & & & & & & 1 & 8 & 1 & 10 & 3 & & 3 & & & & 13 \\
\hline Minas Gerais-S. João d'El-rei & 1 & & 2 & 1 & 4 & & 5 & 2 & 7 & 18 & 3 & 21 & 3 & & 3 & 35 \\
\hline Minas Gerais-Rio das Mortes-Prados (Arraial) & & & & & & & 1 & & 1 & & 1 & 1 & & & & 2 \\
\hline Minas Gerais-Rio das Mortes-S. José & & & & & & 1 & & 1 & 2 & 1 & & 1 & & & & 3 \\
\hline Minas Gerais-S. António da Casa Branca & & & & & & & 2 & & 2 & & & & & & & 2 \\
\hline Minas Gerais-S. Pedro do Fanado & & & & & & & & & & & & & 1 & & 1 & \\
\hline Minas Gerais-Sabará & & & & & & 3 & 13 & 6 & 22 & 6 & 7 & 13 & 4 & 1 & 5 & \\
\hline Minas Gerais-Sabará-N"N Sr. da Encarnação & & & & & & & & & & 1 & & 1 & & & & 1 \\
\hline Minas GeraisSanta Bárbara & & & & & & & 2 & 2 & 4 & & & & & & & \\
\hline Minas Gerais-Sabará-Santa Rita & & & & & & & 1 & & 1 & & & & & & & 1 \\
\hline Minas Gerais-Santa Luzia & & & & & & & & 1 & 1 & 2 & & 2 & & & & \\
\hline Minas Gerais-Sabará-S. Miguel de Piracicaba & & & & & & & & & & & & & 1 & & 1 & 1 \\
\hline Minas Gerais-Serro Frio & & & & & & & 4 & 5 & 9 & 2 & 2 & 4 & & & & 13 \\
\hline Minas Gerais-Serro Frio-Vila do Príncipe & & & & & & & & & & & 2 & 2 & & & & \\
\hline Minas Gerais-Sumidoiro & & & & & & & 1 & & 1 & & & & & & & \\
\hline Minas Gerais-Tejuco (Arraial de) & & & & & & & & & & 7 & 2 & 9 & & & & 9 \\
\hline Minas Gerais-Vila Boa & & & & & & & & 1 & 1 & & & & & & & \\
\hline & & & & & & 7 & 32 & 8 & 47 & 13 & 7 & 20 & 6 & & 6 & 73 \\
\hline
\end{tabular}




\begin{tabular}{|c|c|c|c|c|c|c|c|c|c|c|c|c|c|c|c|c|}
\hline Designação & $\begin{array}{l}1600- \\
1640 \\
\end{array}$ & $\begin{array}{r}1641- \\
1680 \\
\end{array}$ & $\begin{array}{r}1681- \\
1700 \\
\end{array}$ & $\begin{array}{c}1701 \\
1720 \\
\end{array}$ & Total & $\begin{array}{r}1721- \\
1740\end{array}$ & $\begin{array}{l}1741- \\
1760\end{array}$ & $\begin{array}{c}1761- \\
1771 \\
\end{array}$ & Total & $\begin{array}{l}1772- \\
1790\end{array}$ & $\begin{array}{r}1791- \\
1810 \\
\end{array}$ & Total & $\begin{array}{l}1811- \\
1830 \\
\end{array}$ & $\begin{array}{r}1831- \\
1850 \\
\end{array}$ & Total & TOTAI \\
\hline Minas Gerais-Vila Rica-Guaripiranga & & & & & & & 3 & & 3 & 2 & & 2 & & & & 5 \\
\hline Minas Gerais-Vila Rica-Itaberaba & & & & & & & & & & & & & 1 & & 1 & 1 \\
\hline Total & & & & & 4 & & & & 225 & & & 128 & & & 33 & 390 \\
\hline Pará & & & 2 & & 2 & & 1 & 2 & 3 & 7 & 7 & 14 & 6 & 4 & 10 & 29 \\
\hline Pará-Belém & & & & & & 3 & 2 & 1 & 6 & 1 & 1 & 2 & 5 & & 5 & 13 \\
\hline Para-Cachoeira do Rio Arari & & & & & & & & & & & & & 1 & & 1 & 1 \\
\hline Pará-Monte Alegre & & & & & & & & & & & 1 & 1 & & & & 1 \\
\hline Total & & & & & 2 & & & & 9 & & & 17 & & & 16 & 44 \\
\hline Paraiba do Norte & & & & & & & 1 & & 1 & 2 & & 2 & 1 & & 1 & 4 \\
\hline Paraiba do Norte-Va Real do Brejo da Areia & & & & & & & & & & & & & 1 & & 1 & 1 \\
\hline Total & & & & & & & & & 1 & & & 2 & & & 2 & 5 \\
\hline Permambuco & 25 & 25 & 26 & 13 & 89 & 36 & 27 & 12 & 75 & 44 & 30 & 74 & 24 & 19 & 43 & 281 \\
\hline Pernambuco-Alagoa & & & & 1 & 1 & & & & & 1 & 1 & 2 & & & & 3 \\
\hline Pernambuco-Bananeiras & & & & & & & & & & & & & 1 & & 1 & 1 \\
\hline Permambuco-Barra do Rio Grande & & & & & & & & & & & & & 1 & & 1 & 1 \\
\hline Pcrnambuco-Campo Largo & & & & & & & & & & & & & 1 & & 1 & 1 \\
\hline Pernambuco-Goiana & & & & & & & 1 & & 1 & 1 & & 1 & 1 & & 1 & 3 \\
\hline Pernambuco-Olinda & & & 2 & 1 & 3 & 4 & & & 4 & 1 & & 1 & 1 & & 1 & 9 \\
\hline Pcrnambuco-Recife & & & & & & & 3 & 1 & 4 & 3 & 1 & 4 & 5 & & 5 & 13 \\
\hline Pernambuco-Serinhém & & & & & & & & & & & & & 1 & & 1 & 1 \\
\hline Pernambuco-Sertão de & & & & & & & & & & 1 & & 1 & & & & 1 \\
\hline Total & & & & & $\Perp 3$ & & & & 84 & & & 83 & & & 54 & 314 \\
\hline Piauí-Oeiras & & & & & & & & & & 1 & 1 & 2 & 1 & & 1 & 3 \\
\hline Piauí-Pernaguá & & & & & & & & & & & & & 1 & & 1 & 1 \\
\hline Total & & & & & 1 & & & & & & & 2 & & & I & 4 \\
\hline Porto Seguro-Vila Verde do Prado & & & & & & & & & & & & & 1 & & 1 & 1 \\
\hline Rio de Janeiro & 2 & 19 & 50 & 28 & 99 & 143 & 84 & 80 & 307 & 81 & 44 & 135 & 62 & 41 & 103 & 644 \\
\hline Rio de Janeiro-Cabo Frio & & & & & & & & $\mathbf{2}$ & 2 & & & & & & & 2 \\
\hline Rio de Janeiro-Campos & & & & & & & & & & & 2 & 2 & 2 & 1 & 3 & 5 \\
\hline Rio de Janeiro-Campos de Goitacazes & & & & & & & & & & & 4 & 4 & 10 & 7 & 17 & 21 \\
\hline Rio de Janeiro-llha do Catalão & & & & & & & & & & & 1 & 1 & & & & 1 \\
\hline Rio de Janeiro-llha Grande & & & & & & 1 & & & 1 & & & & & & & 1 \\
\hline Rio de Janeiro-Parablba & & & & 1 & 1 & 2 & 4 & 1 & 7 & 8 & 1 & 9 & & & & 17 \\
\hline Rio de Janeiro - Inhomerim & & & & & & & & & & 1 & & 1 & & & & 1 \\
\hline
\end{tabular}




\begin{tabular}{|c|c|c|c|c|c|c|c|c|c|c|c|c|c|c|c|c|}
\hline Designação & $\begin{array}{l}1600- \\
1640\end{array}$ & $\begin{array}{l}1641- \\
1680 \\
\end{array}$ & $\begin{array}{l}1681- \\
1700 \\
\end{array}$ & $\begin{array}{l}1701- \\
1720 \\
\end{array}$ & Total & $\begin{array}{r}1721- \\
1740 \\
\end{array}$ & \begin{tabular}{|c|}
$1741-$ \\
1760 \\
\end{tabular} & $\begin{array}{c}1761- \\
1771 \\
\end{array}$ & Total & $\begin{array}{r}1772- \\
1790 \\
\end{array}$ & $\begin{array}{r}1791- \\
1810\end{array}$ & Total & $\begin{array}{l}1811- \\
1830 \\
\end{array}$ & $\begin{array}{l}1831- \\
1850 \\
\end{array}$ & Total & TOTAL \\
\hline Rio de Janeiro-Laguna & & & & & & & & 1 & 1 & & 1 & 1 & & & & 2 \\
\hline Rio de Janeiro-Nossa Senhora da Conceição & & & & & & & & 1 & 1 & & & & & & & 1 \\
\hline Rio de Janeiro-Parati & & & & & & & & & & & 1 & 1 & 2 & & 2 & 3 \\
\hline Rio de Janeiro-Parati-Na Senhora dos Remédios & & & & & & & & 1 & 1 & & & & & & & 1 \\
\hline Rio de Janeiro-Magé & & & & & & & & & & 1 & 1 & 2 & & & & 2 \\
\hline Rio de Janeiro-S. Maria de Maricá & & & & & & & & & & & 1 & 1 & 1 & & 1 & 2 \\
\hline Rio de Janeiro-Vila do Campo & & & & & & & & 1 & 1 & & 1 & 1 & & & & 2 \\
\hline Total & & & & & 99 & & & & 314 & & & 149 & & & $12 \lll$ & 688 \\
\hline Rio Grande do Norte & & & & & & & & & & & & & 1 & & 1 & 1 \\
\hline Rio Grande do Sul & & & & & & & & & & & 1 & 1 & 7 & 2 & 9 & 10 \\
\hline Rio Grande do Sul-Pelotas & & & & & & 1 & & & 1 & & & & & & & 1 \\
\hline Rio Grande do Sul-Porto Alegre & & & & & & & & & & & & & & 1 & 1 & 1 \\
\hline Rio Grande do Sul-Viamão & & & & & & & & & & & 3 & 1 & & & & 1 \\
\hline Rio Grande do Sul-Vila do Rio Pardo & & & & & & & & & & & & & 1 & & 1 & 1 \\
\hline Total & & & & & & & & & 1 & & & 2 & & & 11 & 14 \\
\hline Santa Catarina & & & & & & & 1 & & 1 & & 1 & 1 & & & & 2 \\
\hline S. Paulo & & 2 & 1 & 1 & 4 & 8 & 10 & 7 & 25 & 15 & 4 & 19 & 6 & 3 & 9 & 57 \\
\hline S. Paulo Iguaçu & & & & & & & & & & & & & & 1 & 1 & 1 \\
\hline S.Paulo-Itu & & & & & & & & & & & 1 & 1 & 2 & & 2 & 3 \\
\hline S. Paulo-Mogimirim & & & & & & & & & & & & & 1 & & 1 & 1 \\
\hline S. Paulo-Paranaguá & & & & & & 1 & & & 1 & & & & & & & 1 \\
\hline S-Paulo-Santos & 1 & 2 & 1 & 1 & 5 & 9 & 8 & 7 & 24 & 1 & 6 & 7 & & 1 & 1 & 37 \\
\hline S. Paulo-Vila Bela da Princesa & & & & & & & & & & & & & 1 & & 1 & 1 \\
\hline S. Paulo-Vila Nova do Príncipe & & & & & & & & & & & & & 1 & & 1 & 1 \\
\hline Total & & & & & 9 & & & & 50 & & & 27 & & & 16 & 102 \\
\hline Sergipe d'El-Rei & & & & & & & 1 & & 1 & & & & 1 & 2 & 3 & 4 \\
\hline Sergipe d'El-Rei-Santa Luzia & & & & & & & & 1 & 1 & & & & & & & 1 \\
\hline Total & & & & & & & & & 2 & & & & & & 3 & 5 \\
\hline Não identificados & & & & & 2 & & & & 5 & & & 2 & & & 2 & 11 \\
\hline TOTAL & & & & & 473 & & & & 1152 & & & 598 & & & 538 & 2761 \\
\hline
\end{tabular}

